Butler University

From the SelectedWorks of Chad M. Bauman

2017

Christian Responses to Discrimination and Violence in India and Sri Lanka: Avoidance, Advocacy, and Interfaith Engagement

Chad M Bauman 


\section{Christian Responses to Discrimination and Violence in India and Sri Lanka: Avoidance, Advocacy, and Interfaith Engagement}

\section{Chad M. Bauman \& James Ponniah}

To cite this article: Chad M. Bauman \& James Ponniah (2017) Christian Responses to Discrimination and Violence in India and Sri Lanka: Avoidance, Advocacy, and Interfaith Engagement, The Review of Faith \& International Affairs, 15:1, 68-78

To link to this article: http://dx.doi.org/10.1080/15570274.2017.1284395

Published online: 28 Mar 2017.

Submit your article to this journal $\pi$

Q View related articles $\asymp$

View Crossmark data $\complement$ 


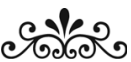 \\ CHRISTIAN RESPONSES TO DISCRIMINATION AND VIOLENCE IN INDIA AND SRI LANKA: AVOIDANCE, ADVOCACY, AND INTERFAITH ENGAGEMENT}

By Chad M. Bauman (D) and James Ponniah

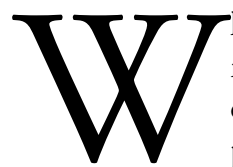

hile India and Sri Lanka are both modern democracies with constitutions that provide general protections for minority groups, in both countries Christians are victimized by various forms of social harassment, legal discrimination, and occasionally even violence. ${ }^{1}$ Though there are key differences, in both countries those who oppose Christianity, and particularly conversion to Christianity, are generally motivated by a religiously inflected nationalism (Hindu in India, Buddhist in Sri Lanka) that considers Christian proselytization both a debased, politically motivated religious practice, and a threat to the demographic superiority of the religious majority. Despite these similarities, electoral politics in the last few years have set the two countries on divergent paths, with Indians handing a resounding political victory to the nationalist-leaning Bharatiya Janata Party (BJP) in 2014, and Sri Lankans, a year later, rejecting a president who had encouraged the growth of Buddhist nationalism in favor of a candidate widely perceived to be more secular and inclusive. In this article, we provide the political and historical context necessary to understand these

Chad M. Bauman is Professor of Religion and Chair of the Department of Philosophy, Religion, and Classics at Butler University. His earliest research focused on the interaction of lowcaste Christians and Hindus in colonial India and culminated in a book, Christian Identity and Dalit Religion in Hindu India, 18681947, that won the prize for Best Book in Hindu-Christian Studies, 2006-2008, from the Society for Hindu-Christian Studies. His most recent book is Pentecostals, Proselytization, and Anti-Christian Violence in Contemporary India (Oxford University Press, 2015).

James Ponniah is Assistant Professor of the Department of Christian Studies at the University of Madras, Chennai. He is the author of a monograph, The Dynamics of Folk Religion in Society:

Pericentralisation as Deconstruction of Sanskritisation (2011), and co-editor of Dancing Peacock: Indian Insight into Religion and Redevelopment (2010), Committed to the Church and the Country (2013), and Identity, Difference and Conflict: Postcolonial Critique (2013). His areas of research include folk religions of India, popular Catholicism, and Dalit Christianity. 
complicated issues, delineate Indian and Sri Lankan Christians' experiences of marginalization, legal discrimination, and violence, and then describe their responses to these experiences.

\section{India}

\section{Political/Historical Context}

Census figures, which probably at least slightly undercount Christians, suggest that they comprise a mere $2.3 \%$ of the Indian population. Christians existed in what is today southern India from at least the $4^{\text {th }}$ century, and possibly significantly earlier. India's ancient Christians seem to have enjoyed a position of relatively high status and relatively cordial relations with their non-Christian neighbors (Bayly 1989). The arrival of European colonizers and missionaries after 1498 altered these relations in a variety of significant ways, among which the most important were (1) by associating Christianity with the legacy of colonialism and foreign intervention and (2) by shifting Christianity's demographic center of gravity away from its ancient high-status Christian communities to the newer, primarily lower-caste communities that converted in the colonial era, thereby creating the impression, among many, that Christianity was a low-caste faith. If the first of these changes made Christianity the target of nativist critique, the latter left it vulnerable to caste prejudice.

That nativist critique percolated throughout the colonial era, but gained significant traction and a clear articulation only in the 1920 s, with the emerging ideology of Hindutva. According to the ideology's proponents, the strength and unity of the Indian nation depends on its "Hindu-ness" (Hindutva). In 1925, the Rashtriya Swayamsevak Sangh ("National Volunteer Organization") became the first organization founded upon this ideology and remains the "Sangh" of the Sangh Parivar ("Family of the Sangh"), a conglomeration of social, religious, and political organizations all rooted in the idea of Hindutva (and including the BJP, which now rules at the center). Those who ascribe to the ideology of Hindutva consider Christianity a foreign, predatory religion and have resisted its growth in India rhetorically, by countering Christian missionary activity with their own, by promoting various forms of legal discrimination against Christians (and other religious minorities), by harassing Christian evangelists and prospective/recent converts, and —at times—by encouraging, justifying, or even taking part in violence against Christians.

\section{Indian Christian Experiences of Harassment, Discrimination, and Violence}

One significant form of repression faced by India's Christians is legal. India's "personal law" code, which governs matters like marriage, divorce, and inheritance, and differs depending on one's religious community, disadvantages converts to Christianity by denying them rights of inheritance and child custody that would have been theirs if they had not converted. Similarly, low-caste converts to Christianity (and Islam) lose advantageous access to reservations set aside for low-caste "Hindus" (construed broadly, to include Buddhists, Jains, etc.) in the civil service, legislative bodies, and educational institutions. The clearest manifestation of discriminatory legislation, however, is in individual state "Freedom of Religion" bills that are active in half a dozen states. These "anti-conversion" laws, as their opponents call them, prohibit conversion by "force, fraud, and inducement," and in some cases even require prior notice or registration by potential converts and/or investigation by local officials into the purity of the convert's motives before official permission for conversion is granted. The ambiguous phrasing of the lawseven the promise of heaven could be construed as an "inducement"-leaves them open for abuse. Moreover, the fact that these laws often expressly do not in any similar way manage or restrict conversion or reconversion to Hinduism makes it plain that Christians (and, secondarily, Muslims) are their real target. Section 295(A) of India's penal code, which forbids acts "intended to outrage religious feelings," and "insulting" religious beliefs, has likewise been used to harass and cow Christian evangelists. Muddying the waters yet further, a 1977 Supreme Court decision upholding the constitutionality of such laws explicitly ruled that the Indian 
Constitution's protection of religious

"propagation" did not include the right to intentionally seek or encourage the conversion of another person (Richards 2016).

In addition to forms of legal harassment and discrimination like these, India's Christians are frequently the target of acts of intimidation, vandalism, and even physical violence. Such acts have increased in frequency since the late 1990s, and now occur several hundred times each year. For the most part, these incidents are isolated and sporadic, involve locally specific actors and grievances, and target specific pastors, evangelists, converts, or churches. In these more isolated antiChristian attacks, lower-caste and more forcefully and openly evangelistic Christians and Christian communities (e.g. evangelicals and Pentecostals) are disproportionately targeted. Occasionally, however, anti-Christian violence becomes widespread and regional, involving an influx of out-of-towners who indiscriminately target Christians in general. The most destructive of these roving riots in modern India continued for many months in 2007-2008, in Kandhamal, Odisha, where at least 50 people (both Hindus and Christian, but mostly the latter) died, while dozens more were beaten, shot, stabbed, sexually assaulted, or forcibly removed from their homes. At one point during the violence, there were around 30,000 Christian refugees in the region. In these rare but dramatic riot contexts, the targeting of specific Christian groups is less perceptible.

\section{Indian Christian Responses to Repression}

The harassment, discrimination, intimidation, and violence experienced by India's Christians has provoked a number of responses, some proactive and creative, others reactionary or borne of sheer desperation. Below, we describe the range of Christian responses to repression under five broad headings: (1) flight, (2) interfaith engagement, (3) evangelistic innovation, (4) political activism, and (5) self-segregation.

One response to anti-Christian harassment and violence is flight. While experiences of harassment and violence encourage some Christians to migrate outside of India altogether, the far more common pattern is internal migration. The previously discussed riots in Kandhamal, Odisha, provoked the largest scale internal migration of Christians in recent decades. Perhaps as many as 25,000 of the 30,000 refugees produced by the Kandhamal riots permanently left their villages for Odisha's urban centers or other states altogether (National Peoples Tribunal on Kandhamal 2010). As a result, Kandhamal is today a far more homogeneously Hindu space than it was before the riots (Bauman 2014).

Interfaith engagement has been a second Christian response to experiences of discrimination and violence. While there is a long history of Christian interfaith engagement and projects of theological "indigenization" in India, such efforts became significantly more common after the riots in Kandhamal and those they inspired afterward in the state of Karnataka. For example, Christians in these areas increased their interfaith engagement and reworked their religious celebrations to make them more accessible to non-Christians. Some we interviewed, like Archbishop Bernard Moras of Bangalore, insisted that interfaith work on projects of concern to and in solidarity with other religious groups was in fact "true evangelization."

Third, as the Archbishop's assertion implies, many Indian Christians have responded to the hostility with which proselytization is met by reconceptualizing both the aims and methods of Christian mission. A Christian leader in Kandhamal, for example, attested to a renewed emphasis on making certain Christian humanitarian aid was given to all, especially tribal Hindus, to avoid giving the impression that Christian aid was given only to the Christian poor. Similarly, many evangelical and Pentecostal Christians have refined their methods, eschewing confrontational styles of evangelism, like those involving street preaching or the use of megaphones and other amplification systems. Such forms of evangelism have now been largely replaced with methods that utilize friendship and business networks and commence only after evangelists have received explicit invitations to share the gospel. It is important to point out, however, that the eschewal of such methods has not been universal. Some Christians still consider more confrontational methods of evangelism their duty, and the only 
really effective way to disturb what they understand to be the damning, apathetic attachment of nonChristians to their faiths.

A fourth Christian response to experiences of discrimination and violence has been political activism. Over the last decade, Indian Christians have more vigorously fought for their own and others' legal and political rights through organizations like the Alliance Defending Freedom (ADF) International. The Alliance partners with Christian organizations across the denominational spectrum to promote religious freedom in India by training Christians (and others) in human rights and Indian constitutional law, by providing legal training, support, and representation for victims of discrimination; and by advocating for the rights of India's religious minorities abroad. $^{2}$

Christians have pressed for their political rights in other ways as well, such as through demonstrations and strikes, and have protested their treatment by periodically shutting down their vast networks of highly regarded schools. They sought help from sympathetic Hindus, from other minorities, especially Muslims, and from opposition parties in states ruled by political parties allied with the Sangh Parivar. They engaged even those hostile towards them in dialogue and called upon Christians worldwide to advocate on their behalf with the Indian government. Christian willingness to work with and on behalf of non-Christians, or on political projects involving people of multiple faiths, have helped Christians create solidarity and support for their own causes among non-Christian peoples. For example, their increased involvement in land rights, anti-exploitation, and regional language promotion projects have created good will among other faith communities.

One of the clearest effects of anti-Christian discrimination and hostility in India since the late 1990s has been to spur the formation and growth of interdenominational networks and alliances like the United Christian Forum for Human Rights and to encourage a greater ecumenical spirit among India's various Christian communities. Reinvigorated regional and national ecumenical networks have not only contributed to Christian political unity, they have also occasionally provided a platform for the release of demands, such as when a Christian ecumenical alliance in Bangalore, Karnataka drafted a memorandum that succeeded in pressuring the Karnataka government to release 500 million rupees of a Christian minority fund to repair structures damaged in the 2008 antiChristian violence, and to uplift poor Christians.

Intra-Catholic unions like the lay-led All India Christian Council (AICC) and the All India Catholic Union have also been politically active. The AICC, formed in 1999 in the wake of a round of anti-Christian riots in the Dangs, Gujarat, and the killing of Australian missionary Graham Staines and his two sons, allies itself with other Christian groups to advocate for the rights of Christians of all denominations in India, as well as for the rights of other religious minorities and lower-caste Indians, regardless of their religious affiliation. The AICU focuses its advocacy work on India's 16 (or so) million Catholics, though like the AICC, it also occasionally advocates more broadly for other marginalized and minority groups.

Christians in India have also responded to the stress of their situation by calling on a variety of international Christian and human rights organizations. The AICC, for example, works with Christian Solidarity Worldwide (UK), the Dalit Freedom Network (Australia, Canada, Germany, UK, and USA), Stefanus Alliance International (Norway), and Release International (UK). They have, additionally, successfully presented their views to international political organizations. For example, John Dayal and Ajay Singh, leaders, respectively, of the AICC and the Odisha Forum for Social Action, worked closely with the United Nations Special Rapporteur who visited Odisha and Karnataka after the violence there in 20072008.

As we noted above, growth in Christian ecumenism has been one clear, positive effect of 
Indian Christians' experiences of discrimination, repression, and hostility. But there is an important exception: certain of India's mainline and higher-status Christian communities have responded to the persecution of Christians in India by intentionally distancing themselves from its primary victims. Though the response is not necessarily a productive one, this self-segregation is conspicuous and significant enough that we list it here as a fifth form of Christian response to persecution.

Self-segregation is particularly noticeable among mainline Protestant, Orthodox, and Catholic communities of high status in Goa and Kerala, and in wealthier urban neighborhoods elsewhere. These communities tend to enjoy relatively cordial relations with their nonChristian neighbors, a result both of their higher social status and of their non-evangelistic predisposition. With much to lose, and themselves sharing with other anti-Christian groups certain prejudices against the aggressive evangelism of India's evangelicals and Pentecostals (not to mention against lower-caste communities), these mainstream groups not only distance themselves from the primary victims of anti-Christian hostility, but often even join in on their excoriation in an effort to curry favor with anti-Christian parties in power. Unfortunately, by framing themselves as the "good" Indian Christians and blaming those victimized by antiChristian discrimination and violence for their own fate, these self-segregating Christians leave their fellow Christians isolated, and therefore more vulnerable to anti-Christian predation. What we are seeing in the self-segregation of Christian groups like these, according to John Dayal, is the self-interested attempt of higherstatus Christian communities to preserve their status by establishing good relations with those in power, while "the rest of the Christian community goes to the dogs." 3

As social theorists like Anthony Giddens and Sherry Ortner remind us, social action is dually constructed, constrained by social facts that delimit the range of possible actions, but also made unpredictable by the force of individual creativity, will, and imagination (Giddens 1979, 210-12; Ortner 1984, 129). The range of Indian
Christian responses to experiences of discrimination and hostility are a testament to that force. At the same time, the fact that migration was a response so many Kandhamali Christians were forced to choose in the context of the riots of 2007 and 2008 demonstrates the power of social constraints to limit human options and agency. The massive migration of Christians away from Kandhamal also distinguishes the Indian Christian situation from that of Christians in Sri Lanka, to which we now turn. While internal migration was an obvious and significant feature of Sri Lanka's long civil war, large numbers of Sri Lankan Christians have never been forced to flee large-scale campaigns of anti-Christian violence. Apart from migration, however, many of the strategies adopted by India's Christians-interfaith engagement, evangelistic innovation, political activism; and self-segregation-have been adopted by Sri Lankan Christians as well.

\section{Sri Lanka}

\section{Political/Historical Context}

Sri Lanka, an island nation, sits off the southeastern coast of India. Its population is divided primarily between three ethnic groups: the Sinhalese $(75 \%$ of the population and mostly Buddhist), the Tamils (15\% of the population and mostly Hindu), and the Moors (10\% of the population, and mostly Muslim descendants of Arab traders). In terms of religious diversity, close to $70 \%$ of Sri Lankans are Buddhist, while around $13 \%$ are Hindu, 10\% are Muslim, and $8 \%$ are Christian. The Christian population is distinct from other religious communities in Sri Lanka in that it cuts across ethnic divides; Tamils and Sinhalese comprise a roughly even proportion of the Christian population.

It is possible that a small Christian community existed in Sri Lanka in the early centuries of the Common Era, but as in India, the real growth of the Christian community came only with European explorers-Portuguese, Dutch, and then British—who planted colonies and churches on the island beginning in the $16^{\text {th }}$ century. In the $19^{\text {th }}$ century, aggressive evangelization under British rule provoked a 
revival of Buddhism that drew upon Sri Lanka's ancient connection to that faith, a connection that is celebrated (and likely at least somewhat exaggerated) in national chronicles like the Mahavamsa (Arasaratnam 1977, 164; Devotta 2007, 6).

After independence, Sri Lanka's Christians, who were politically privileged and disproportionately powerful under the British, began to be displaced, at first because of the somewhat more fair and open political competition of the independent era, and then by a rising tide of Sinhalese nationalism. Beginning in the 1950s, nationalist politicians replaced English with Sinhala as the national language, nationalized private Christian schools, and eventually (in the 1970s) wrote Buddhism into the country's constitution as its "foremost religion" (while still in many other ways preserving religious freedom for religious minorities). The Sinhalese-Tamil civil war that began in 1983 and ended only in 2009 both expressed and further entrenched Sinhalese Buddhist nationalism in Sri Lankan society (Arasaratnam 1977, 171-178; Johnson 2012, 80; Matthews 2007, 460).

Somewhat surprisingly, during this same period Sri Lanka's Buddhist monks became increasingly public and forceful supporters of Sinhalese Buddhist nationalism. When a popular nationalist and anti-Christian monk, Soma Thero, died under mildly suspicious circumstances in 2003, rumors circulated that Christians had been responsible for his death. These rumors contributed to a rise in antiChristian rhetoric and violence and gave birth to a new political party, the Jathika Hela Urumaya (JHU), that put forward a slate of 280 monks for the 2004 parliamentary elections. Several of them won and made good on their campaign promises by proposing a national law against "unethical conversions." The law was clearly inspired by similar laws in India and, like those laws, was primarily aimed at preventing conversion to Christianity (Berkwitz 2008; Deegalle 2004; Devotta and Stone 2008). But the JHU had overplayed its hand, and the proposed law, which drew immediate national and international condemnation, was never passed. Nevertheless, a significant portion of the Sri Lankan population resonates with the JHU's brand of ethno-religious nationalism, so much so that after the Tamils were finally defeated at the end of the civil war in 2009, President Mahinda Rajapaksha, perhaps looking for a new "threat" to unify the Sinhalese, began to encourage, or at least tacitly condone attacks on Sri Lankan Christians by radical Buddhist groups like the Bodu Bala Sena ("Buddhist Power Force/Army"). In 2015, however, in a surprise election result, Rajapaksha was defeated by the more secular and inclusive Maithripala Sirisena. Though Christians continue to suffer legal discrimination and occasional acts of violence, Christians we interviewed just a few months after the election expressed a great deal of optimism that their situation would continue to improve. "You felt it," one Christian we interviewed said, "The day after the election you felt it: the freedom."

\section{Sri Lankan Christian Experiences of Harassment, Discrimination, and Violence}

Nevertheless, Christians in Sri Lanka continue to suffer under various forms of legal discrimination, social marginalization, and even violent attack. Legal discrimination is enabled by an unresolved tension in the constitution, which simultaneously privileges Buddhism as the nation's "foremost religion" and protects each citizen's "freedom of thought, conscience and religion, including the freedom to have or to adopt a religion or belief of his choice," and the "freedom, either by himself or in association with others, and either in public or in private, to manifest his religion or belief in worship, observance, practice or teaching." While this latter protection suggests there should be no constraints whatever on religious freedom in Sri Lanka, the government's obligation to "protect and foster" Buddhism can be used to defend laws circumscribing conversion to other faiths. Exploiting the space created by this tension, politicians with anti-Christian tendencies have set up a variety of legal hurdles for Christian organizations with regard to their official incorporation, the procurement of building permits, etc. Such politicians have been 
particularly inclined to regulate Christian organizations that mix evangelism and charitable activity on the grounds that this mixing constitutes an undesirable allurement (Matthews 2007, 464; Woods 2013).

In the new millennium, Sri Lanka's Christians have also experienced an increase in threats, vandalism, harassment and violence. The number of incidents increased significantly in 2003, after Soma Thero's assassination, and in recent years have ranged from a few dozen to more than a hundred a year (Devotta and Stone 2008, 41; Weiberg-Salzman 2014, 299). While incidents involving violence leading to death or serious injury have declined from their apex in the years between Soma Thero's assassination and the end of Rajapaksha's rule, Christians do still regularly experience acts of intimidation, harassment, threats, and discrimination. ${ }^{4}$

\section{Sri Lankan Christian Responses to Repression}

Sri Lankan Christians have responded to their experiences in a variety of ways, employing both shorter- and longer-term strategies to press for their rights (and, sometimes, those of other minorities). In this section, we catalog those responses under the following four headings: obfuscation, accommodation, collaboration, and advocacy.

\section{Obfuscation}

At times, Sri Lankan Christians have sought to ward off persecution by downplaying or hiding their Christian identity. Some evangelical Christians, for example, have reduced or ended their public evangelism. Similarly, to circumvent legal hurdles preventing their official legal incorporation, some Christian churches and missions have begun incorporating themselves as "companies," "trusts," or "societies."

Congregations denied building permits have built "community centers" instead. Some of these strategies are of course illegal, desperate responses borne of necessity, but nevertheless demonstrating the creativity and perseverance of the Sri Lankan Christian community.

\section{Interfaith Contact and Cooperation}

As in India, Christians in Sri Lanka are often accused of being denationalized and are suspect due to their historical connection to foreign and colonial-era Christianity. And also as in India, Christians in Sri Lanka have attempted to undermine this complaint by accommodating or integrating into Christianity elements of the island's larger religious communities. Many Sri Lankan Christian pastors and priests now encourage their congregants to celebrate Sinhalese/Buddhist new year, to offer drinks or gifts to Buddhist devotees at Vesak, or to participate in Buddhist death rituals with their grieving Buddhist friends. While such strategies are particularly noticeable among Sri Lanka's mainstream Protestant and Catholic communities, we were surprised to find even evangelicals and Pentecostals (who are often theologically predisposed against accommodation strategies) encouraging or engaging in them. In this regard, Sri Lanka's evangelical and Pentecostal Christians differed significantly from those we met among their counterparts in India.

Though Christians have collaborated with non-Christians in Sri Lanka for decades, one effect of Christians' more recent experiences of harassment, discrimination, and violence has been to encourage and motivate such efforts even further. Sri Lankan Christians engage in a variety of interfaith projects, like those sponsored by the Tulana Research Centre for Encounter and Dialogue, founded in 1974 by Aloysius Pieris, the well-known and widely published Catholic priest and scholar of Buddhism. At times, dialogue spills over into collaborative action. For example, to counter the claim that Christian social work represents an illegitimate form of allurement, some Christian churches and NGOs have begun collaborating with Buddhists and state agencies in their provision of social service. Anglicans have at times even offered medical services in Buddhist temples to avoid any suggestion of ulterior motives. Methodists have collaborated with Buddhists on projects intended to promote interethnic harmony. Catholics have invited Buddhists to come teach courses in their seminaries. This Christian engagement with 
people of other faiths extends, also, to Sri Lanka's religious minorities. For example, the Religious Liberty Commission (RLC) of the National Christian Evangelical Alliance of Sri Lanka (NCEASL) has created interfaith legal teams and has collaborated with Muslim leaders to document and provide representation for victims of anti-Muslim violence. And many Christian pastors we met, from across the denominational spectrum, had organized interfaith and interethnic sports or cultural events in conflict-prone areas.

As members of a religious minority that transcends particular ethnicities in Sri Lanka, Christians have a natural interest in working for minority religious rights and attempting to ameliorate inter-ethnic and inter-religious relations. But Christians also engage in a variety of interfaith projects aimed at building up civil society, protecting the environment, and protecting the poor, marginalized, and disenfranchised. They have worked arm and arm with members of other faiths for farmers' rights, to mitigate the negative environmental impact of rubber plantations, to preserve forests, to protest increases in diesel prices, and so forth.

Both during and since the end of the civil war, Christians have engaged with members of other faiths to address the humanitarian needs of those affected by the hostilities and their aftermath. For example, the Catholic Caritas Sri Lanka-SEDEC has organized blood donation drives, intentionally, literally, and in symbolically potent ways mixing the blood of Sinhalese and Tamil Sri Lankans. Christians founded and remain prominent participants in the now nonsectarian and interfaith National Peace Council, which works to undermine enduring post-civil war hostilities between the Sinhalese and Tamils, and has been particularly effective in addressing lingering resentment over the intentional wartime Sinhalization and Buddhisization of Tamil Hindu spaces carried out by Sinhalese forces. Sri Lanka's Christians are engaged in a simply astounding array of such creative, collaborative, and often appealingly grassroots interfaith projects to promote peace, protect the environment, and address injustice.

\section{Advocacy}

Sri Lankan Christians' experiences of discrimination and hostility have also prompted them to press for their own rights, as well as for religious liberties more generally. The aforementioned RLC of the NCEASL stands out in this regard. The RLC has lobbied and continues to lobby for the equitable management and treatment of Christians and other religious minorities in government offices and ministries. The RLC also offers education, assistance, and pro bono legal advice, representation, and document preparation services to Christian individuals and communities victimized by antiChristian discrimination and violence.

In addition to working domestically, Sri Lanka's Christians have also garnered support for their causes abroad. Representatives of NCEASL, and well-known Christian leaders and activists, such as Fr. Sarath Iddamalgoda, Jehan Perera, Godfrey Yogarajah, Lakshan Dias, and Mario Gomez, have given testimony and/or led advocacy delegations to the United Nations, the United Nations High Commissioner for Refugees, the United States Commission on International Religious Freedom, the French Observatory for the Protection of Human Rights Defenders, and the Swiss Sri Lanka Brief. In their work with such organizations, Sri Lanka's Christians often advocate not only for themselves, but also for other religious minorities, decrying all manner of human rights violations and infringements upon religious freedom in Sri Lanka.

As the foregoing paragraphs indicate, the response of Sri Lanka's Christian community to experiences of discrimination and violence has been significant and, in our assessment, generally productive. Sri Lanka's Christians recognize and accept their minority status and have demonstrated the propensity to carry out their affairs in ways that indicate respect for the nation's more numerically dominant religions (esp. Buddhism and Hinduism). Even more importantly, perhaps, many Sri Lankan Christians have taken their opponents' concerns seriously, making adjustments to avoid causing unnecessary offense (e.g. by avoiding provocative 
forms of street preaching or by working with Buddhist organizations in the distribution of social services so they could not be construed as an "allurement"). Sri Lankan Christians have also demonstrated a remarkable degree of persistence and creativity, finding ways to work with others, and to work around impediments, in their pursuit of freedom and a more equitable society for all.

It is, of course, hard to assess the effects of their efforts, particularly since many of them are of relatively recent provenance. While Christians have succeeded in addressing certain

discriminatory laws and regulatory regimes, they have not, of course, gained the privileges accorded to Buddhism as the "foremost religion" in Sri Lanka's constitution. And while their efforts to improve inter-religious and inter-ethnic relations have been extensive, the impact of those efforts will probably never be fully known. That said, one obviously positive affect of dealing with antiChristian discrimination and hostility has been to increase Christian unity. While, as in India, Sri Lanka's more established and mainstream Christians have sometimes been tempted to distance themselves from evangelical and Pentecostal Christians because of the latter's reputation for provoking anti-Christian hostility, we were struck by what we perceived to be a powerful sense of Christian ecumenism and interdenominational solidarity that was no doubt the result of Christian collaborative work on the projects outlined above.

\section{Conclusion}

The experiences of Christians in India and Sri Lanka are similar in many ways. Christians in both countries at times find themselves harassed or attacked by activists associated with organizations and political parties informed by majoritarian religious nationalisms (Hindu in India; Buddhist in Sri Lanka) whose vision of the ideal nation excludes adherents of "foreign" religions. Christians in both countries also suffer legal discrimination, though the discrimination experienced by Sri Lanka's Christians is somewhat more overt, due to the special place given to Buddhism in the nation's constitution. Christians in both countries continue to suffer from the legacy of their religion's association with foreign, colonial power, as well as from the widespread perception that South Asian Christians continue to receive large-scale infusions of wealth from their affluent western coreligionists. These associations and perceptions make Christians in both countries vulnerable to the claim that theirs is a religion that illegitimately grows through political coercion and the inducements of wealth and power. They also make Christians vulnerable to the accusation of introducing "foreign" ideals of human rights and equality that threaten "traditional" social structures and hierarchies. Relatedly, in both countries, Christians suffer from the widespread perception that proselytization is a political, not a properly religious act. This perception probably at least partially accounts for the fact that the Christians most openly and assertively engaged in evangelism are, in both countries, also the Christians most likely to be harassed, discriminated against, and attacked.

In both India and Sri Lanka, incidents of violence increased around the end of the 1990s, reaching their height after the turn of the millennium. There were undoubtedly locally distinct factors and catalytic events that account for this timing, but the fact that anti-Christian hostilities should rise almost simultaneously in these two countries despite their distinct postcolonial trajectories (e.g. Sri Lanka's decadeslong civil war, which has no equivalent in India) suggests that we must consider the possibility of cross-pollination and the likelihood that there were certain transnational dynamics affecting both countries in similar ways. Indeed, it has already been established that India's anticonversion laws served as inspiration for those proposed in Sri Lanka (Devotta and Stone 2008, 51). And processes of globalization and economic liberalization that gained strength and momentum around the end of the last century may have added strength, as we have argued elsewhere, to anti-western and anti-Christian movements in both countries (Bauman 2013).

Similarities in the sources and manifestations of anti-Christian hostility in India and Sri Lanka are no doubt partly responsible for similarities in the responses of Christians there. As indicated 
above, Christians in both countries have addressed instances of legal discrimination through circumvention, obfuscation, and advocacy for legal reforms. Christians in both countries have also revised their liturgies and theologies to be more inclusive and to assimilate local religious and cultural practices and symbols. Christians in both countries have altered, scaled back, or abandoned their evangelistic efforts. Christians in both contexts have also reached out to people of other denominations, worked collaboratively with and on behalf of adherents of other minority faiths, and drawn upon international religious, political, and human rights networks to gain support for their causes.

There are important differences that condition and constrain the range of responses available Christians in the two countries. In
India, anti-Christian violence is fueled by antiDalit prejudice to an extent not seen in Sri Lanka. There are also the aforementioned constitutional differences because of which Sri Lankan Christians cannot press for equal rights on constitutional grounds as easily as their counterparts in India. Nevertheless, Sri Lankan Christian express far more confidence in the ability of their judicial system to address injustices and prosecute the perpetrators of anti-Christian violence than do their Indian counterparts.

Among all of the differences between the Indian and the Sri Lankan situations, however, perhaps the most important is the one discussed in the introduction, that is, the divergent recent election results, which have given hope to Sri Lanka's Christians while stoking fears among their counterparts in India.

Notes

1. We thank the following for their support of the research from which this article derives: the Center for Civil and Human Rights at the University of Notre Dame; the Religious Freedom Project, Berkley Center for Religion, Peace \& World Affairs, Georgetown University; the John Templeton Foundation; the Templeton Religion Trust; the Center for Religion and Civic Culture at the University of Southern California; the Desmond Tutu Center for Peace, Reconciliation, and Global Justice at Butler University and Christian Theological Seminary, the American Academy of Religion, and our respective universities. We have presented some of the material in this article more thoroughly in Bauman and Ponniah (2016).

2. See, for example, the testimony of ADF attorney, Tehmina Arora, before the US House of Representatives (available at http://www. adfmedia.org/files/AroraTestimony20140211.pdf, accessed on March 10, 2016).

3. Personal interview (via Skype) on March 7, 2016. Similar criticisms have been made of other prominent Christian figures, like those of Catholic Archbishop Oswald Cardinal Gracias and Julio Ribeiro.

4. The NCEASL, for example, recorded over a hundred such incidents in 2014. Data on the incidents reported can be downloaded from NCEASL's website: Accessed October 15 2015. https://sichurchattacks.crowdmap.com/reports/download

\section{ORCID}

Chad M. Bauman (iD http://orcid.org/0000-0002-1670-7428

\section{References}

Arasaratnam, S. 1977. "The Christians of Ceylon and Nationalist Politics." In Religion in South Asia: Religious Conversion and Revival Movements in South Asia in Medieval and Modern Times, edited by Geoffrey Oddie, 163-182. London: Curzon Press.

Bauman, Chad M. 2013. "Hindu-Christian Conflict in India: Globalization, Conversion, and the Coterminal Castes and Tribes." Journal of Asian Studies 72: 633-653.

Bauman, Chad. 2014. "The Inter-Religious Riot as a Cultural System: Globalization, Geertz, and Hindu-Christian Conflict." In Constructing Indian Christianities: Caste, Culture, and Conversion, edited by Chad Bauman and Richard Fox Young, 188-214. Delhi: Routledge.

Bauman, Chad, and James Ponniah. 2016. "Christianity and Freedom in India: Colonialism, Communalism, Caste, and Violence." In Christianity and Freedom, Vol. 2: Contemporary Perspectives, edited by Allan Hertzke and Timothy Shah, 222-253. Cambridge: Cambridge University Press.

Bayly, Susan. 1989. Saints, Goddesses and Kings: Muslims and Christians in South Indian Society 1700-1900. Cambridge: Cambridge University Press.

Berkwitz, Stephen. 2008. "Resisting the Global in Buddhist Nationalism: Venerable Soma's Discourse of Decline and Reform." Journal of Asian Studies 97: 73-106. 
Deegalle, Mahinda. 2004. "Politics of the Jathika Hela Urumaya Monks: Buddhists and Ethnicity in Contemporary Sri Lanka." Contemporary Buddhism 5: 83-103.

Devotta, Neil. 2007. Sinhalese Buddhist Nationalist Ideology: Implications for Peace and Conflict Resolution in Sri Lanka. Washington, DC: East-West Center Washington.

Devotta, Neil, and Jason Stone. 2008. "Jathika Hela Urumaya and Ethno-Religious Politics in Sri Lanka." Pacific Affairs 81: 31-51.

Giddens, Anthony. 1979. Central Problems in Social Theory. London: Macmillan.

Johnson, Debra. 2012. "Sri Lanka—A Divided Church in a Divided Polity: The Brokerage of a Struggling Institution." Contemporary South Asia 20: 77-90.

Matthews, Bruce. 2007. "Christian Evangelical Conversions and the Politics of Sri Lanka." Pacific Affairs 80: 455-467.

National Peoples Tribunal on Kandhamal. 2010. Waiting for Justice: A Report. New Delhi: Peace \& ANHAD.

Ortner, Sherry B. 1984. "Theory in Anthropology Since the Sixties." Comparative Studies in Society and History 26: 126-166.

Richards, lan. 2016. "Poles Apart: The Debate on Religious Conversion in Post-Independence India." Doctoral diss., University of Toronto.

Weiberg-Salzman, Mirjam. 2014. "The Radicalization of Buddhism in the Twentieth and Twenty-First Centuries: The Buddhist Sangha in Sri Lanka." Politics, Religion \& Ideology 15: 283-307.

Woods, Orlando. 2013. "The Spatial Modalities of Evangelical Christian Growth in Sri Lanka: Evangelism, Social Ministry, and the Structural Mosaic." Transactions of the Institute of British Geographers 38: 652-664. 